\title{
$\mathrm{ARB}$ 법에 의한 인탈산동의 결정립초미세화 및 고강도화
}

\author{
이성희 ${ }^{\dagger}$ - 한승전* 임차용*

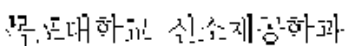

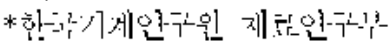

\section{Ultra Grain Refinement and High Strengthening of Deoxidized Low-Phosphorous Copper by Accumulative Roll-Bonding Process}

\author{
Seong-Hee Lee", Seung-Zeon Han* and Cha-Yong Lim* \\ Department of Advanced Materials Science and Engineering, Mokpo National University, \\ Muan-gun, Chonnam, 534-729, Korea \\ *Department of Materials Technology, Korea Institute of Machinery and Materials, \\ 66 Sangnam-dong, Changwon, 641-010, Korea
}

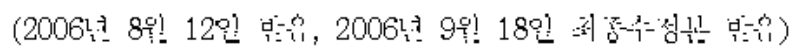

\begin{abstract}
A deoxidized low-phosphorous (DLP) copper was processed by acomulative roll-bonding (ARB) for ultra grain refinement and high strengthening. Two copper sheets $1 \mathrm{~mm}$ thick, $30 \mathrm{~mm}$ wide and $300 \mathrm{~mm}$ long are first degreased and wire-brushed for sound bonding. The sheets are then stacked to each other, and roll-bonded by about $50 \%$ reduction rolling without lubrication at ambient temperature. The bonded sheet is then out to the two pieces of same dimensions and the same procedure was repeated to the sheets up to eight cycles $(\varepsilon \sim 6.3)$. TEM observation revealed that ultrafine grains were developed after the 4 th cycle, and their size decreased at higher cycles. Tensile strength of the copper increased with the equivalent strain, and it reached $547 \mathrm{MPa}$ which was 3 times higher than that of the initial material. It is concluded that the ARB process is an effective method for high strengthening of the DLP copper.
\end{abstract}

Key words accumulative roll-bonding, deoxidized low-phosphorous copper, ultrafine grain, mechanical property.

\section{1. 서 론}

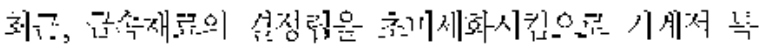

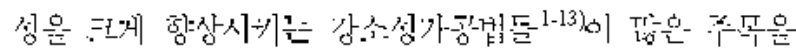

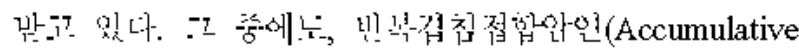
Roll-Bonding, ARB)겁흔 인속겅정이 가항한 안현을 이

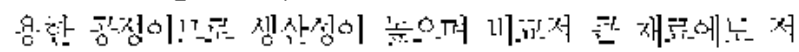

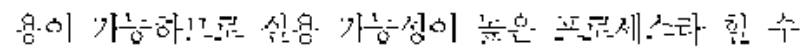

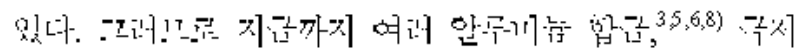

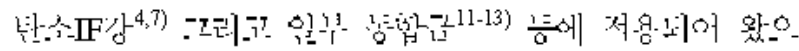

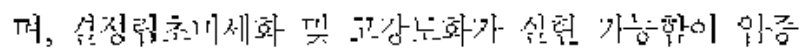

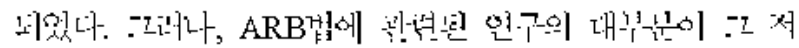

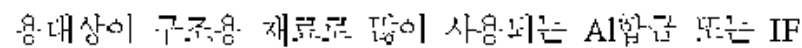

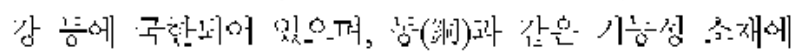

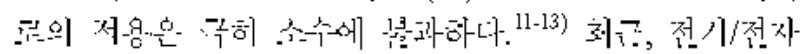

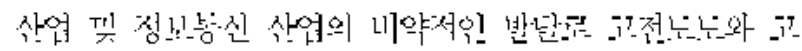

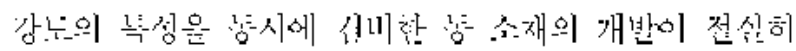

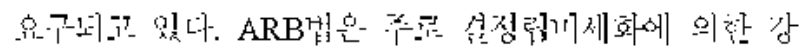

${ }^{\dagger}$ E-Mail : shlee@mokpo.ac.kr

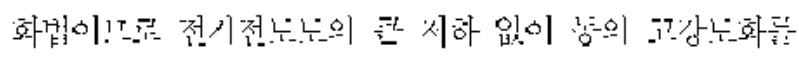

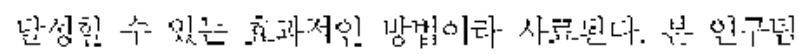

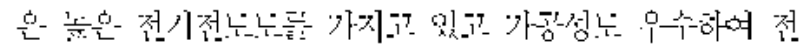

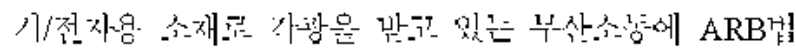

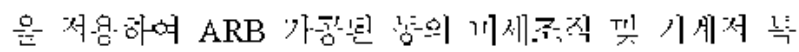

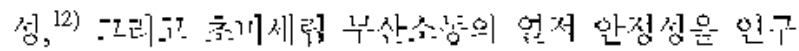

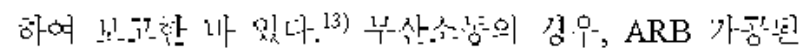

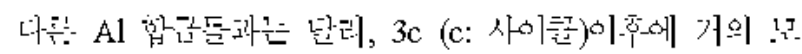

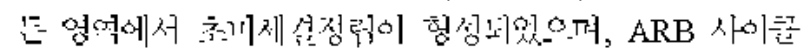

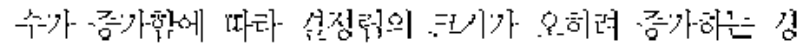

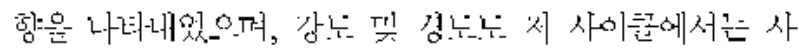

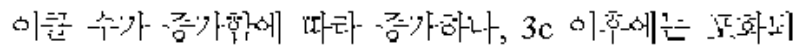

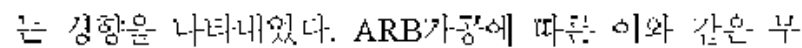

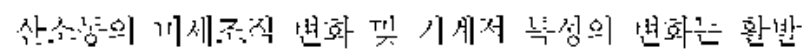

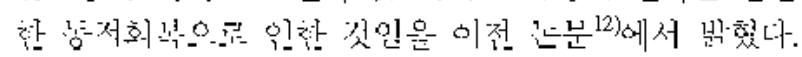

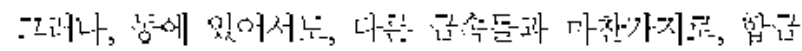

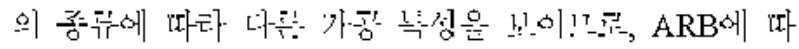

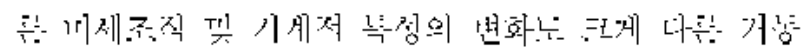

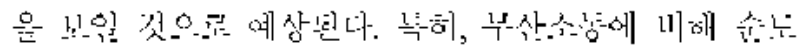

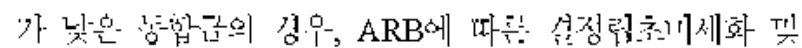


고강도화가 더욱 효과적으로 달성될 가능성이 있다. 그 러므로 본 연구에서는 인탈산동에 $\mathrm{ARB}$ 법을 적용하여, $\mathrm{ARB}$ 에 따른 미세조직의 변화 및 기계적 특성 변화를 조 사하였다.

\section{2. 실험 방법}

본 연구에 사용된 동은 시판용 인탈산동 $(99.9 \%)$ 으로 그 화학조성을 Table 1에 나타내었다. ARB전에 시편을 $440^{\circ} \mathrm{C}$ 에서 5 시간 동안 완전 어닐링하여 내부의 잔류변형 을 제거하였다. $\mathrm{ARB}$ 공정을 위해 두께 $1 \mathrm{~mm}$, 폭 $30 \mathrm{~mm}$, 길이 $300 \mathrm{~mm}$ 의 인탈산동 판재가 준비되었다. $\mathrm{ARB}$ 공정 은 이전 논문 ${ }^{12}$ 과 동일한 방법에 의해 상온, 부윤활 조 건에서 8 사이클 까지 진행되었다.

$\mathrm{ARB}$ 전후의 인탈산동의 미세조직은 광학현미경 및 투 과전자현미경(TEM)으로 관찰하였다. 광학현미경조직은 $\left(\mathrm{NH}_{4}\right)_{2} \mathrm{~S}_{2} \mathrm{O}_{8}$ 의 $10 \%$ 수용액에서 화학부식한 후 횡단면(TD 면)에서 관찰하였다. TEM관찰용 시편은 $253 \mathrm{~K}$ 온도에서 $\mathrm{CH}_{3} \mathrm{COOH}: \mathrm{HNO}_{3}=2: 1$ 의 비율로 혼합한 에칭액으로 jet- polishing 하여 준비하였으며, TEM 관찰은 JEOL-2000FX 로 $200 \mathrm{kV}$ 의 전압에서 행하였다. 기계적 성질은 상온에 서의 인장시험 및 경도시혐으로 평가하였다. 인장시혐을 위한 시편은 인장 방향이 압연 방향과 평행하도록 방전 가공기로 잘라서 준비하였다. 인장시혐은 평행부의 길이 가 $32 \mathrm{~mm}$, 폭이 $6 \mathrm{~mm}$ 의 인장 시편을 사용하여 Instron type의 인장 시혐기를 사용하여 $10^{-3} \mathrm{~s}^{-1}$ 의 일정한 변형율 속 도로 행하였다. 경도시험은 마이크로 비커스 경도계를 사 용하여 $300 \mathrm{~g}$ 의 하중에서 10 초간의 압입시간으로 행하였다.

\section{3. 결과 및 고찰}

\section{1 미세조직}

Fig. 1은 ARB의 사이클 수에 따른 인탈산동의 광학 현미경 조직사진의 변화(TD면)를 보여준다. $\mathrm{ARB}$ 전의 조 직은 완전 어닐링된 상태이므로 평균입경이 $45 \mu \mathrm{m}$ 의 전 형적인 재결정 조직을 나타넨다(Fig. 1a). $1 \mathrm{c}(\mathrm{c}$ : 사이클) 후는 결정립들이 압연방향으로 연신된 전형적인 압연가 공조직을 나타내며, $4 \mathrm{c}$ 및 $8 \mathrm{c}$ 후에는 결정립의 형상을
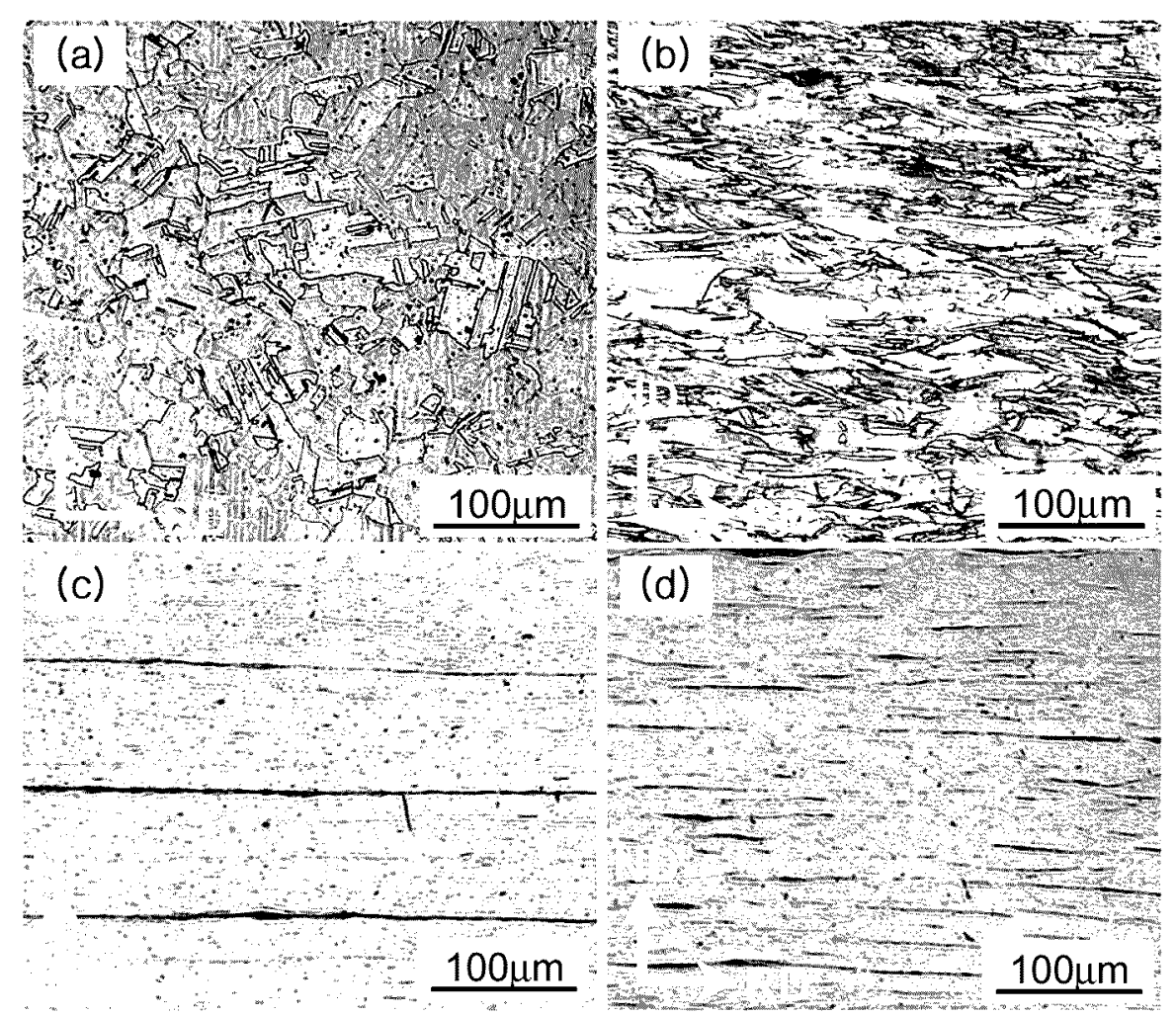

Fig. 1. Optical micrographs of deoxidized low-phosphorous copper before ARB (a), after 1 cycle (b), after 4 cycles (c) and 8 cycles (d) of ARB, respectively.

Table 1. Chemical composition of deoxidized low-phosphorous copper studied.

(wt.\%)

\begin{tabular}{rcccccc}
\hline \hline $\mathrm{Cu}$ & $\mathrm{O}$ & $\mathrm{Pb}$ & $\mathrm{Bi}$ & $\mathrm{Fe}$ & $\mathrm{P}$ & $\mathrm{S}$ \\
\hline Bal. & 0.0005 & 0.017 & $<0.0001$ & 0.0001 & 0.02 & 0.0005 \\
\hline
\end{tabular}




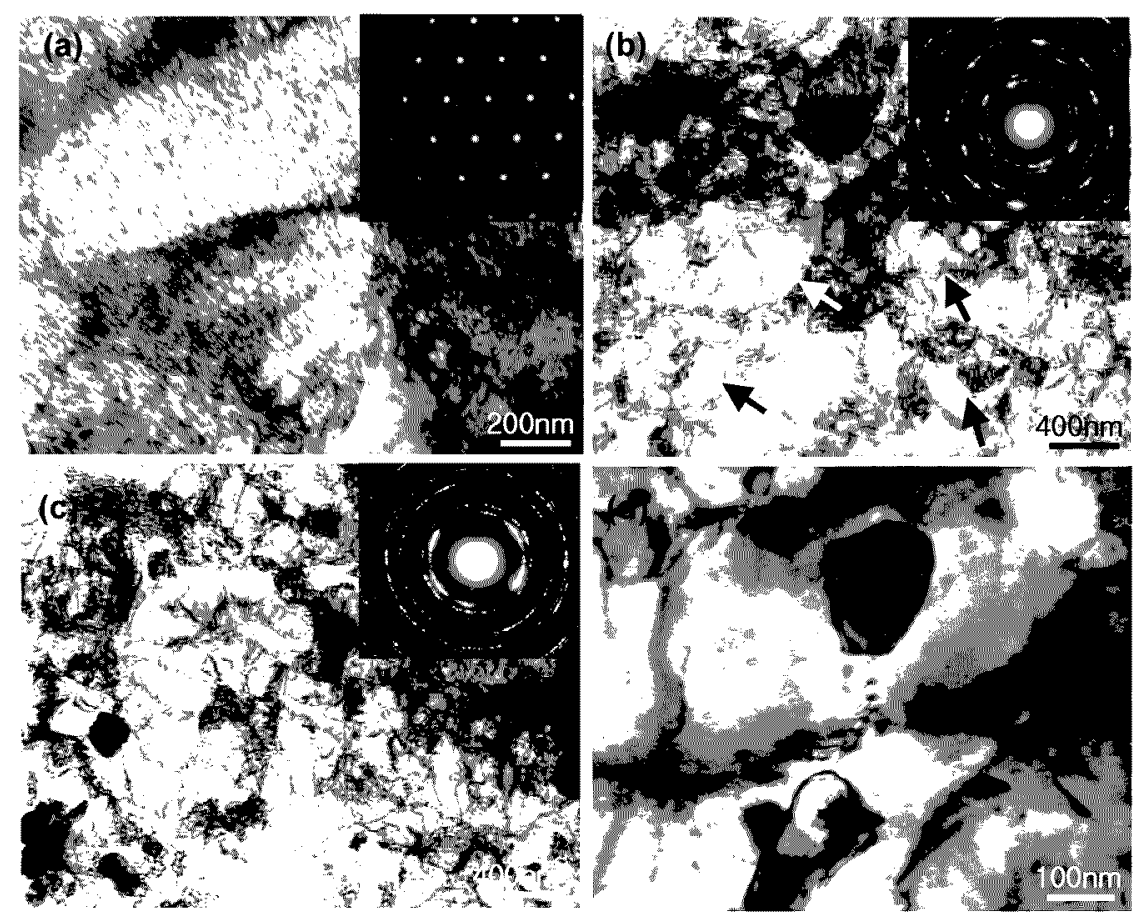

Fig. 2. TEM microstructures and the corresponding SAD patterns of deoxidized low-phosphorous copper processed by ARB of 1 cycle(a), 4 cycles(b), 8 cycles(c) and 8 cycles, magnified(d), respectively. Observed at the plane perpendicular to the normal direction (ND plane).

거의 식별할 수가 없을 정도로 결정립이 미세화됨을 알 수 있다. 이와 같은 $\mathrm{ARB}$ 에 따른 마크로(macro) 조직변 화는 무산소동의 경우 ${ }^{12}$ 와 매우 유사하다.

Fig. 2는 ARB 후에 시편의 두께방향에 수직인 면(ND 면)에서 관찰된 $\mathrm{TEM}$ 조직사진을 나타낸다. 각 조직사진 의 우측상단에 있는 회절도형은 각 조직의 중심에서 직 경 $3 \mu \mathrm{m}$ 범위에 조리개를 삽입하여 찍은 제한시야회절 (selected area diffraction, SAD) 도형을 나타낸다. 1c 후의 시편은 전형적인 가공조직인 전위셀 조직(dislocation cell structure)을 나타낸다. [011] 정대축(zone axis)에서 촬영하여 얻은 $\mathrm{SAD}$ 도형도 단순하고 규칙적인 $\mathrm{FCC}$ 구 조 모양을 나타내고 있으며, 이것은 전위셀 간에 방위차 (misorientation)가 거의 존재하지 않음을 의미한다. $4 \mathrm{c}$ 후 의 시편(Fig. 2 (b))도 $1 \mathrm{c}$ 후의 시편과 유사하게 전위셀 조직을 나타내지만, 셀의 크기가 작아진 것 외에도 화살 표로 표시한 것과 같이 전위밀도가 극히 낮고 선명한 입 계를 가진 아결정립(subgrain)도 관찰되는 것을 확인할 수 있다. 또한, SAD도형도 $1 \mathrm{c}$ 후의 시편과는 달리 회절반 점의 퍼짐현상과 여분의 회절반점도 많이 나타나 있는 것 을 알 수 있다. 이것은 새롭게 형성된 아결정립간에 방 위차가 다소 존재하는 것을 암시해 준다. $8 \mathrm{c}$ 후의 시편 (Fig. $2 \mathrm{c}, 2 \mathrm{~d}$ )은 $4 \mathrm{c}$ 후의 시편과 달리 시편 전면에 걸쳐 초미세한 결정립 조직을 나타내었으며, 전위밀도의 감소, 결정립 크기의 감소 외에도 결정립계가 더욱 선명해진 것
들의 변화가 있음을 확인할 수 있다. SAD도형도 거의 환상(ring pattern)의 회절도형을 나타내고 있으며, 이것 은 초미세결정립들 간에 방위차가 크게 존재함을 암시해 준다. $8 \mathrm{c}$ 후에 형성된 초미세결정립의 확대사진이 Fig. $2 \mathrm{~d}$ 에 나타나 있는데 무산소동에서 관찰되었던 것들과는 달 리 결정립 내부에 내부응력의 잔존을 시사하는 등고선 부 늬를 나타내고 있으며, ${ }^{2,3)}$ 결정립계의 형상도 일반적인 재 결정에서 나타나는 직선적인 모양이 아니다. 이와 같은 초미세결정립은 무산소동보다 오히려 $\mathrm{ARB}$ 에 의해 강소 성가공된 1100 알루미늄 합금르응에서 관찰되는 것과 매 우 유사하다. 이 외에도 $\mathrm{ARB}$ 공정에 따른 인탈산동의 $\mathrm{TEM}$ 미세조직의 형성과정에 있어서 무산소동의 경우 ${ }^{13}$ 와 다른 점은 다음과 같다. 첫째, 거의 모든 영역에 초미세 결정립이 형성되는 것이 무산소동의 경우는 $3 \mathrm{c}$ 인 반면 인탈산동의 경우는 $5 \mathrm{c}$ 이후였으며 인탈산동에서 결정립 초미세화에 더 많은 가공(변형)량이 요구되었다. 둘째, $\mathrm{ARB}$ 에 의해 형성된 초미세결정립의 크기는 인탈산동의 경우 약 $200 \mathrm{~nm}$, 무산소동의 경우 약 $450 \mathrm{~nm}$ 로 인탈산 동에서 더 미세하였다. 셋째, 인탈산동의 경우, $\mathrm{ARB}$ 사 이클 수가 증가함에 따라 형성된 초미세결정립 크기는 다 소 감소하는 경향을 나타내었지만, 무산소동의 경우는 오 히려 증가하는 경향을 나타내었다. ARB공정에 있어서 두 재료간의 이와 같은 미세조직 형성의 차이는 주로 순도 의 영향이 가장 큰 것으로 사료된다. $\mathrm{ARB}$ 공정에 있어 
서의 초미세결정립의 형성 메커니즘은 아직 명확히 밝혀 지지는 않았지만 강소성가공에 의해 국부적으로 방위차 (misorientation)가 큰 영역 [Ashby에 의해 제안된 기하학 적으로 필요한 전위(geometrically necessary dislocation, g-n 전위 $\left.{ }^{14}\right)$ 에 의해 형성됨]이 소성가공열에 의한 단범위 의 확산과정을 거쳐(동적회복) 고경각입계로 전화(轉化) 된 다고 알려져 있다. ${ }^{15)}$ 일반적으로 용질원자들은 전위의 이 동을 방해하거나 원자공공의 이동도를 감소시키므로 동 적회복의 진행을 어럽게 하는 작용을 하므로, $\mathrm{ARB}$ 가공 중에 발생하는 동적회복에 있어서도 순도가 높은 재료에 서 더욱 용이하게 일어난다. ${ }^{16)}$ 또한 용질원자들은 가공 시에 국부변형을 유발하는 역할을 하므로 $\mathrm{ARB}$ 가공 중 에 방위각이 큰 국부 영역을 양산하게 되어 결국에는 결 정립초미세화에 기여하게 된다. 그러므로 $99.9 \%$ 의 순도 를 가진 인탈산동이 $99.99 \%$ 순도를 가진 무산소동에 비 해 국부변형 장소가 많아 더욱 미세한 결정립 조직이 되 었을 것이고 동적회복도 활발히 발생하지 않아 무산소동 에서와 같이 형성된 초미세립의 조대화가 발생하지 않았 을 것으로 사료된다.

\section{2 기계적 성질}

\section{1) 인장 특성}

Fig. 3은 ARB 전과 후의 무산소동의 공칭응력-공칭변 형율(s-s) 곡선을 나타낸다. ARB전의 재료는 완전 어닐 링된 상태이므로 강도가 낮고 비교적 큰 균일 연신율 (uniform elongation)을 나타낸다. 그러나 $1 \mathrm{c}$ 후의 재료 에서는 강도의 증가와 연신율의 감소가 두드러지게 나타 난다. $3 \mathrm{c}$ 이후의 재료들도 $1 \mathrm{c}$ 후의 재료와 유사한 형태 의 곡선을 나타내지만, $1 \mathrm{c}$ 재료에 비해 강도의 증가가 현 저하며 국부 연신율(local elongation)도 다소 증가하는 경 향을 나타낸다. 이와 같은 s-s 곡선의 형태는 무산소동 의 그것과 매우 유사하다. ${ }^{12)}$ Fig. 4는 ARB에 따른 기계 적 성질의 변화를 상당변형량으로 정리한 것이다. 여기

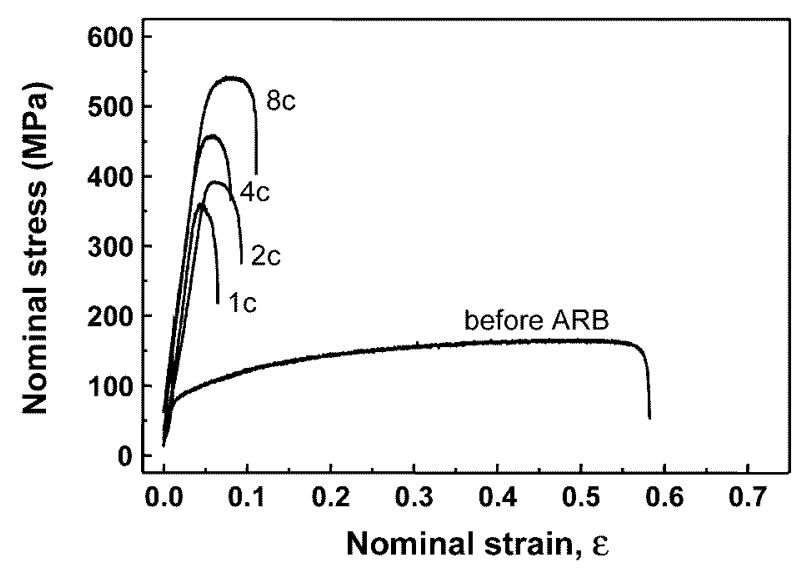

Fig. 3. Nominal stress-strain curves of deoxidized lowphosphorous copper processed by ARB.
서 상당변형량의 크기는 압연시 롤과 제료사이의 마찰로 인해 도입되는 부가적 전단변형량의 크기를 고려하지 않 은 값이며 그 계산식은 다른 논문을 참고하기 바란다. ${ }^{8)}$ 참고를 위하여 그림 내에 $\mathrm{ARB}$ 사이클 수를 기입하였다. 그림과 같이 인장강도는 상당변형량이 증가함에 따라 점 차적으로 중가하여 상당변형량이 $~ 6.3(8 \mathrm{c}$ 후)에서는 $547 \mathrm{MPa}$ 로 초기재료 $(184 \mathrm{MPa})$ 에 비해 무려 3 배 증가한 큰 값을 나타내었다. 이것은 인탈산동에 있어서도 $\mathrm{ARB}$ 법에 의한 고강도화가 충분히 달성될 수 있음을 잘 입증해 준다. 또 한, 이 결과는 $\mathrm{ARB}$ 에 의한 고강도화는 무산소동(초기재 료에 비해 약 2 배 증가)에 비해 인탈산동에서 더 효과 적임을 시사해 준다.

2) 경도

Fig. 5에 ARB 전과 후의 두께방향으로의 경도시험 결

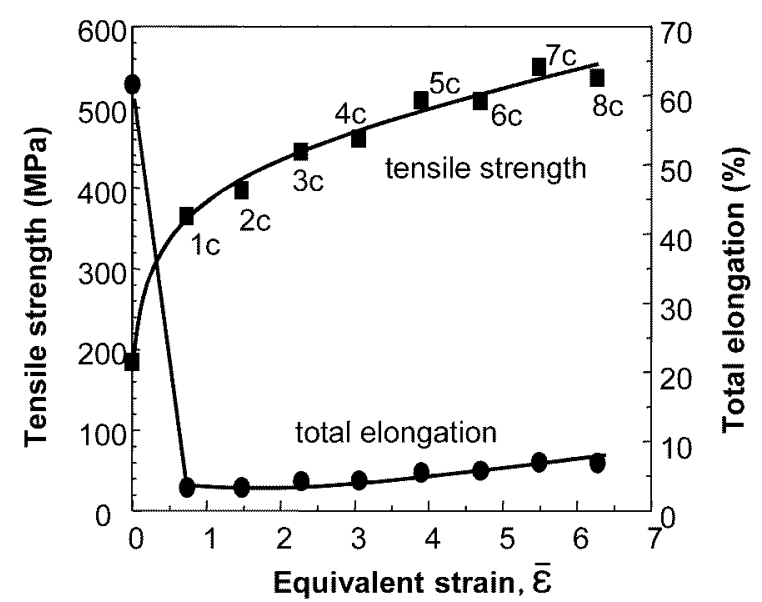

Fig. 4. The variation of mechanical properties of deoxidized low-phosphorous copper with ARB.

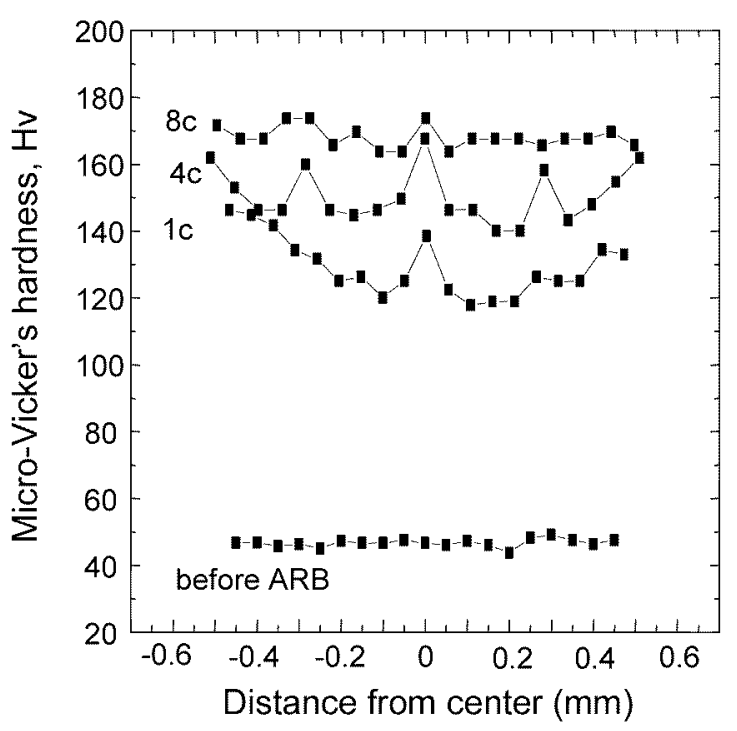

Fig. 5. Micro-Vicker's hardness distribution in thickness direction of deoxidized low-phosphorous copper processed by ARB. 


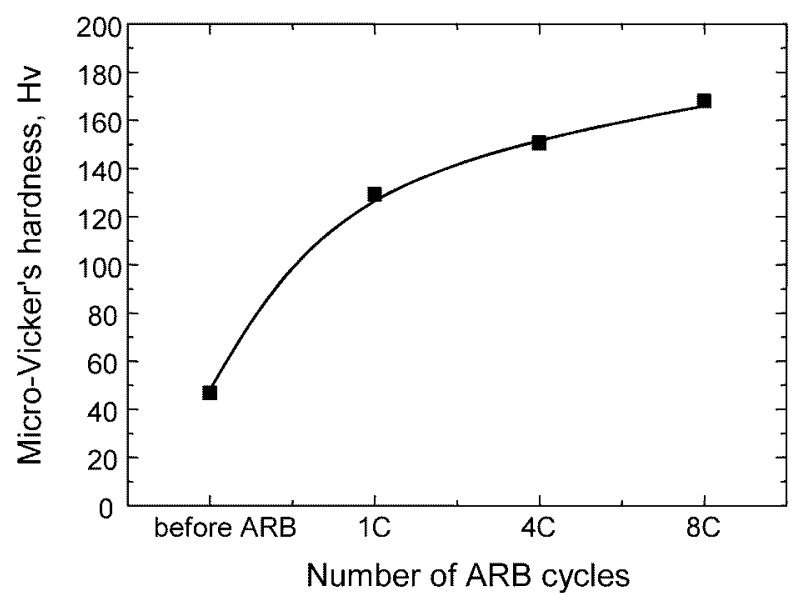

Fig. 6. The variation of hardness of deoxidized lowphosphorous copper with the number of ARB cycles.

과를 나타내었다. $\mathrm{ARB}$ 전의 시편은 두께방향으로 약 $47 \mathrm{Hv}$ 의 균일한 경도 값을 나타내지만 $1 \mathrm{c}$ 후에는 중심 부위와 표면부위에서 큰 값을 나타내는 불균일한 경도분 포를 나타내며, $3 \mathrm{c}$ 후에는 $1 \mathrm{c}$ 후의 재료에 비해 그 불 균일성이 다소 감소하지만 여전히 표면부위 및 일부 접 합부위에서 큰 값을 나타낸다. 그러나 $8 \mathrm{c}$ 이후에는 경도 의 불균일성이 크게 감소하여 비교적 균일한 경도분포를 나타낸다. 중심부위에서 나타나는 큰 경도값은 wirebrushing으로 인해 생긴 가공경화층과 산화물에 기인한 것 이며 표면부위의 큰 경도값은 롤과 재로사이의 마찰로 인 해 도입되는 부가적 전단변형에 기인한 것이다. ${ }^{5}$ 그러나 , $8 \mathrm{c}$ 후의 시편에서는 다른 부위의 상대적인 경도 값의 증가로 인하여 두께방향의 경도의 불균일성이 크게 감소 하게 된다. 이와 같은 두께방향으로의 불균일한 경도분포 는 무산소동과 매우 유사하지만, ${ }^{12)} \mathrm{ARB}$ 사이클 증가에 따 른 경도값의 증가는 인탈산동에서 더 큰 것을 알 수 있 다. Fig. 6은 각 경도값의 평균치를 나타낸 것이다. ARB 사이클 수가 증가함에 따라 경도값이 크게 증가함을 알 수 있다. 이와 같은 $\mathrm{ARB}$ 에 따른 경도의 변화는 인장강 도의 변화(Fig. 4)와 잘 대응한다.

\section{3 전기전도도}

$\mathrm{ARB}$ 에 따른 전기전도도의 변화를 Fig. 7에 나타내었 다. 여기서 IACS(International Annealed Copper Standard) $\%$ 는 고순도 양질의 동의 전기전도도의 평균치를 $100 \%$ 로 정하고 그 상대 전도율을 백분율로 나타내는 것을 말 한다. $\mathrm{ARB}$ 전의 인탈산동의 $\mathrm{IACS} \%$ 가 $78 \%$ 이었으나 $8 \mathrm{C}$ 의 $\mathrm{ARB}$ 가공 후에도 $75 \%$ 로 거의 감소하지 않았음을 확 인할 수 있다. Fig. 8은 본 실험을 통해 얻은 인탈산동 의 강도값을 전기전도도로 정리한 그림이다. 참고로 부 산소동의 결과도 정리하여 나타내었다. 그림을 통하여,

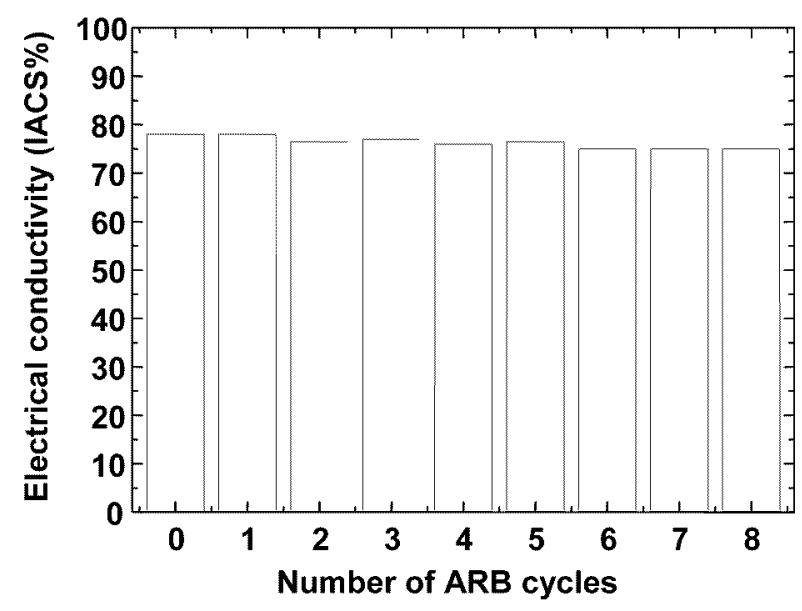

Fig. 7. The variation of electrical conductivity of deoxidized low-phosphorous copper with ARB.

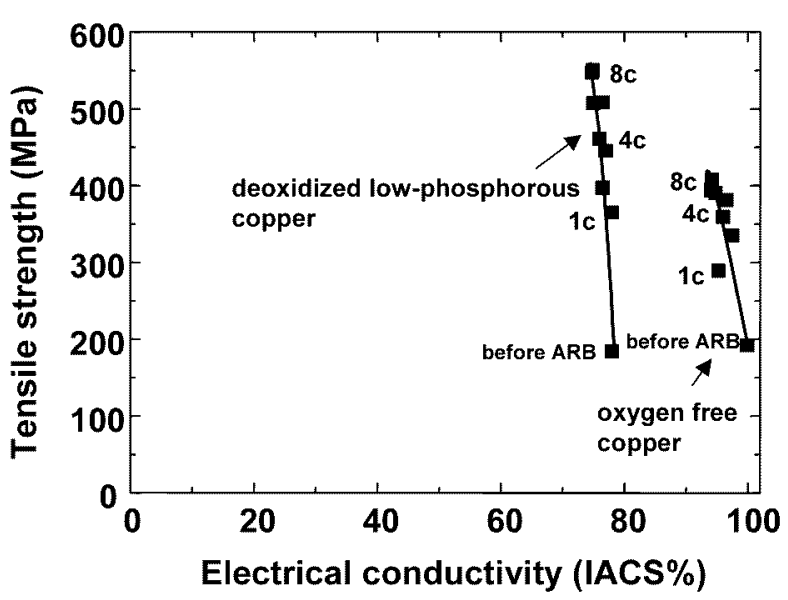

Fig. 8. The relationship between tensile strength and electrical conductivity of the ARB processed copper alloys.

$\mathrm{ARB}$ 가공법은 무산소동과 인탈산동에 있어서 전기전도도 의 큰 손실 없이 강도를 증가시키는데 유효한 가공법이 며, 특히 인탈산동의 고강도화에는 매우 호과적임을 확 인할 수 있다.

\section{4. 결 론}

인탈산동의 결정립초미세화 및 고강도화를 목적으로 $\mathrm{ARB}$ 가공법을 적용하여 미세조직 및 기계적 특성을 조 사한 결과 다음과 같이 요약할 수 있다. $\mathrm{ARB}$ 공정에 따 른 미세조직의 형성과정은 부산소동과는 달리 변형량이 증가함에 따라 결정립미세화가 진전되었으며 $8 \mathrm{c}$ 후에는 $200 \mathrm{~nm}$ 정도의 초미세결정립을 형성하였다. 인장강도는 사 이클 수가 증가함에 따라 크게 증가하여 $8 \mathrm{c}$ 이후에는 초 기재료의 무려 3 배인 $547 \mathrm{MPa}$ 를 나타내었다. $\mathrm{ARB}$ 가공에 


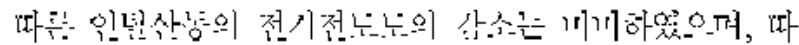

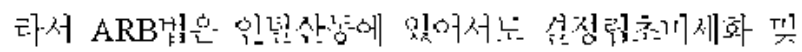

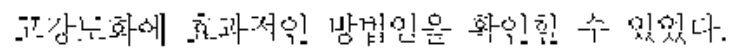

\section{감사의 글}

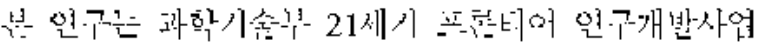

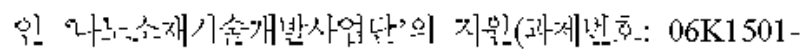

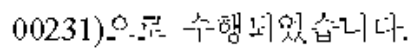

\section{참 고 문 헌}

1. R. Z. Valiev, N. A. Krasilnikov and N. K. Tsenev, Mater. Sci. Eng., A137, 35 (1991).

2. R. Z. Valiev, F. Chmelik, F. Bordeaux, G. Kapwlski and B. Baudelet, Scripta Metall. Mater., 27, 855 (1992).

3. Y. Saito, N. Tsuji, H. Utsunomiya, T. Sakai and R. G. Hong, Scripta Mater, 39, 1221 (1998).

4. N. Tsuji, Y. Saito, H. Utsunomiya and S. Tanigawa, Scripta Mater., 40, 795 (1999).

5. S. H. Lee, Y. Saito, N. Tsuji, H. Utsunomiya and T. Sakai,
Scripta Mater., 46, 281 (2002).

6. S. H. Lee, Y. Saito, T. Sakai and H. Utsunomiya, Mater. Sci. Eng., A325, 228 (2002).

7. S. H. Lee, Y. Saito, K. T. Park and D. H. Shin, Mater. Trans., 43, 2320 (2002).

8. S. H. Lee, H. Inagaki, H. Utsunomiya, Y. Saito and T. Sakai, Mater. Trans., 44, 1376 (2003).

9. Y. Saito, H. Utsunomiya and H. Suzuki, Proc. Inst. Mech. Eng. Ser. B, 215, 947 (2001).

10. J. Y. Huang, Y. T. Zhu, H. Jiang and T. C. Lowe, Acta Mater, 49, 1497 (2001).

11. Y. H. Jang, S. S. Kim, S. Z. Han, C. Y. Lim, C. J. Kim and M. Goto, Scripta Mater., 52, 21 (2005).

12. S. H. Lee, J. Cho, S. Z. Han and C. Y. Lim, Kor. J. Mater. Res., 15, 240 (2005).

13. S. H. Lee, J. Cho, C. H. Lee, S. Z. Han and C. Y. Lim, Kor. J. Mater. Res., 15, 555 (2005).

14. M. F. Ashby, Phil. Mag., 21, 399 (1970).

15. N. Tsuji, R. Ueji, Y. Ito and Y. Saito, Proc. of the 21st Riso Int. Symp. on Mat. Sci., Riso National Laboratory, Denmark, 607 (2000).

16. F. J. Humphreys and M. Hatherly, Recrystallization and Related Annealing Phenomena, 1st ed., p.129, Elsevier Science Ltd., England, (1995). 